\title{
Electrochemical Reduction of Ttz Copper(II) Complexes in the Presence and Absence of Protons: Processes Relevant to Enzymatic Nitrite Reduction. $\left(\mathrm{Ttz}^{\mathrm{R}, \mathrm{R}^{\prime}}=\operatorname{tris}\left(3-\mathrm{R}, 5-\mathrm{R}^{\prime}-1,2\right.\right.$, 4-triazolyl)borate)
}

\author{
Sopheavy Siek ${ }^{\dagger}$, Natalie A. Dixon ${ }^{\ddagger}$, Elizabeth T. Papish ${ }^{\dagger, *}$
}

The University of Alabama, Dept. of Chemistry, 250 Hackberry Lane, Tuscaloosa, AL 35401. 'Past affiliation: Drexel University, Dept. of Chemistry, 3141 Chestnut St., Philadelphia, PA 19104. Current affiliation: Chemours, Inc. 7685 Kiln Delisle Rd, Pass Christian, MS 39571.

*etpapish@ua.edu

\begin{abstract}
Tris(triazolyl)borate $(\mathrm{Ttz})$ is a proton responsive ligand, and the redox potential of Ttz complexes can be altered by protonation. Protonation events can therefore alter the thermodynamics of reduction of copper complexes, and this is relevant to nitrite reduction mediated by copper complexes wherein $\mathrm{Cu}(\mathrm{II})$ reduction to $\mathrm{Cu}(\mathrm{I})$ is the first step. The electrochemical behavior of tris(triazolyl)borate and the corresponding copper complexes, $\mathrm{Ttz}^{\mathrm{tBu}, \mathrm{Me}} \mathrm{CuCl}$ (1) and $\mathrm{Ttz}^{\mathrm{t}}{ }^{\mathrm{Bu}, \mathrm{Me}} \mathrm{CuNO}_{2}$ (2), was investigated under both neutral and acidic conditions. Upon protonation, reduction of $\mathbf{1}$ is shifted more positive $\left(\Delta \mathrm{E}_{\mathrm{pc}}=290 \mathrm{mV}\right)$ upon addition of 1.0 equiv. of acid. This result indicates that ligand protonation facilitates the reduction process, which is also evident from the UV-Vis spectral data. In contrast, with the $\mathrm{Ttz}^{\mathrm{tBuMe}} \mathrm{CuNO}_{2}$ (2) analogue, the reduction peak shifted towards a more negative potential while UV-Vis spectra shows no significant changes as acid is added. This suggests that the protons may not be involved in assisting the redox process but rather lead to decomposition events at reducing potentials. Other electrochemical control studies on a series of compounds, namely $\left(\mathrm{Ttz}^{\mathrm{tBu}, \mathrm{Me}}\right) \mathrm{ZnCl}(\mathbf{3}),\left(\mathrm{Ttz}^{\mathrm{tBu}, \mathrm{Me}}\right) \mathrm{K}(\mathbf{4}), \mathrm{H}\left(\mathrm{Ttz}^{\mathrm{tBu}, \mathrm{Me}}\right)(\mathbf{5})$, and $\mathrm{Htz}^{\mathrm{tBu}, \mathrm{Me}}(\mathbf{6})$, were also conducted with and without acid present. These studies have shown that triazole rings, by themselves and in metal complexes, are not redox active under the conditions we have used. We therefore conclude that the Ttz ligand (including in $\mathbf{1}$ and $\mathbf{2}$ ) is not a site for reduction in our studies.
\end{abstract}




\section{Graphic Abstract}

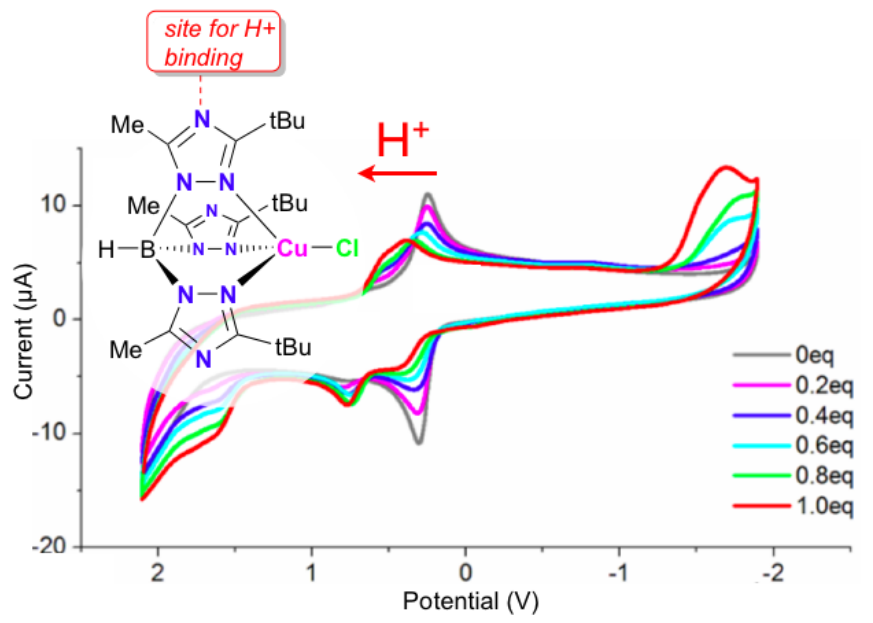

Keywords: Tris(triazolyl)borate ligands; proton responsive ligands; nitrite reduction; copper nitrite reductase; electrochemistry; bioinorganic models. 


\section{Introduction}

Denitrification is a key process in the global nitrogen cycle. Denitrification removes bioavailable nitrogen by converting nitrate and nitrite to nitrogen gas (eq. 1).[1] Copper nitrite reductase $(\mathrm{CuNiR})^{1}$ catalyzes the proton coupled one electron reduction of nitrite $\left(\mathrm{NO}_{2}{ }^{-}\right)$to nitric oxide (NO) (step 2, eq. 1 and eq. 2).[2] The reduction pathway to generate nitric oxide is one method of anaerobic respiration in bacteria.[3] Furthermore, the generation of toxic NO in vivo allows bacteria to avoid our immune system, and thus is relevant to human health.[4]

$$
\begin{aligned}
& \mathrm{NO}_{3}{ }^{-} \rightarrow \mathrm{NO}_{2}{ }^{-} \rightarrow \mathrm{NO} \rightarrow \mathrm{N}_{2} \mathrm{O} \rightarrow \mathrm{N}_{2} \\
& \mathrm{NO}_{2}{ }^{-}+1 \mathrm{e}^{-}+2 \mathrm{H}^{+} \rightarrow \mathrm{NO}+\mathrm{H}_{2} \mathrm{O}
\end{aligned}
$$

Figure 1 illustrates the catalytic cycle of CuNiR.[5-7] It is proposed that a four coordinate $\mathrm{Cu}(\mathrm{II})$-aqua complex binds nitrite and then is reduced to $\mathrm{Cu}(\mathrm{I})$. The resulting $\mathrm{Cu}(\mathrm{I})-\mathrm{NO}_{2}$ complex can further reduced nitrite to form NO upon protonation.[8, 9] There have been many structural and functional model compounds reported that are relevant to $\mathrm{CuNiR}$ and other copper enzymes.[10-17] Some of these studies have elucidated the pathways for nitrite reduction and also which processes compete.[18-20] Enzymatic nitrite reduction typically involves reduction of $\mathrm{Cu}(\mathrm{II})$ to $\mathrm{Cu}(\mathrm{I})$ prior to nitrite reduction (Figure 1, Routes A and $\mathrm{B}$ ). Thus, any factor that influences the redox potential of the $\mathrm{Cu}$ (II) model complex can give insight into what factors facilitate nitrite reduction. Studies have shown that a metal's redox potential and spectroscopic features are influenced by the donor properties of the ancillary ligands.[21-25] For instance, Dilworth et al. reported that $\mathrm{LCu}(\mathrm{II}) \mathrm{NO}_{2}$ complexes supported by the weak donor ligand, $\mathrm{L}_{1}=$ tris-[(benzimidazol-2-yl)methyl]amine, were more readily reduced than complexes of a stronger donor ligand, $\mathrm{L}_{2}=$ tris-(2-aminoethyl)] amine $\left(\mathrm{E}_{1 / 2}=-0.027 \mathrm{~V}\right.$ and $-0.375 \mathrm{~V}$ vs. SCE with $\mathrm{L}_{1}$ and $\mathrm{L}_{2}$, respectively).[26-28] In contrast to altering the electronic properties by synthetic changes, our group has demonstrated that the electron donating properties of Ttz ligand can be tuned by protonation at the fourth position nitrogen atom of the triazole ring (Figure 2, right).[29] This point is described further below.

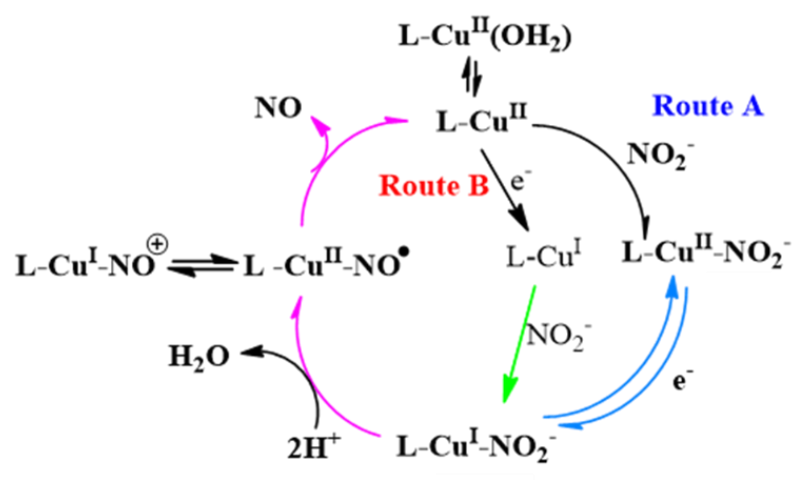

Figure 1: The key steps in enzymatic nitrite reduction by $\mathrm{CuNiR}$

\footnotetext{
${ }^{1}$ Abbreviations used in this article: copper nitrite reductase (CuNiR), cyclic voltammetry (CV), formic acid (FA), ligand to metal charge transfer (LMCT), trifluoroacetic acid (TFA), tris(triazolyl)borate (Ttz), tris(pyrazolyl)borate $(\mathrm{Tp})$.
} 
Bulky tris(3,5-R,R'-1, 2, 4-triazolyl)borate ( $\mathrm{Ttz}^{\mathrm{R}, \mathrm{R}}$ ) ligands support low coordinate metalcenters that are suitable for catalysis.[8, 29-37] Ttz complexes of copper(I) show that electrophilic C-H activation reactions can be enhanced by ligand protonation.[29] Ttz ligands offer facial coordination and ease of steric modification at the metal center similar to the more commonly used tris(3-R-5-R'-1,2-pyrazolyl)hydroborate $\left(\mathrm{Tp}^{\mathrm{R}, \mathrm{R}^{\prime}}\right)$ ligands (Figure 2).[38-46] Unlike Ttz, Tp complexes have poor water solubility and are sensitive to acids, thus preventing their use as catalysts in water, alcohols, or acidic solutions. $\mathrm{Ttz}^{\mathrm{R}, \mathrm{R}}$ is a weaker electron donor compared to $\mathrm{Tp}^{\mathrm{R}, \mathrm{R}}$,,$[35,47]$ as evident from the difference in $\mathrm{CO}$ stretching frequencies (solid state) for $\left(\mathrm{Ttz}^{\mathrm{tBu}, \mathrm{Me}}\right) \mathrm{Cu}^{\mathrm{I}} \mathrm{CO}\left(2080 \mathrm{~cm}^{-1}\right)$ and $\left(\mathrm{Tp}^{\mathrm{tBu}, \mathrm{Me}}\right) \mathrm{Cu}^{\mathrm{I}} \mathrm{CO}\left(2060 \mathrm{~cm}^{-1}\right) \cdot[30]$
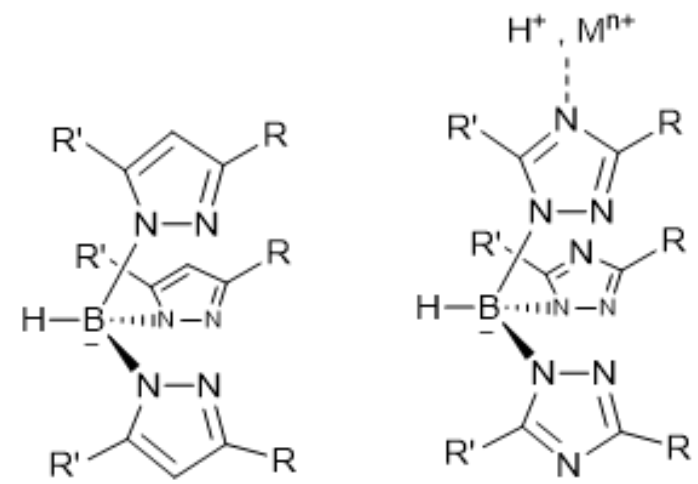

Figure 2: General structure of $\mathrm{Tp}^{\mathrm{R}, \mathrm{R}^{\prime}}$ (left) and $\mathrm{Ttz}^{\mathrm{R}, \mathrm{R}^{\prime}}$ (right). The dotted line shows how the fourth position nitrogen and can bind (exodentate) to protons, metal ions, or other Lewis acids.

Uniquely for Ttz, the apical-nitrogen on the triazolyl (N4) can bind $\mathrm{H}^{+}$or a metal ion $[31,37]$ as shown in Figure 2 (right) to alter the electronic properties in situ.[29-31] Our prior work has shown that $\left(\mathrm{Ttz}^{\mathrm{tBu}, \mathrm{Me}}\right) \mathrm{Cu}^{\mathrm{I}} \mathrm{CO}$ can be treated with various Bronsted acids to produce new protonated complexes with significant electronic changes.[29] Specifically, upon adding just one equivalent of $\mathrm{H}^{+}$to $\left(\mathrm{Ttz}^{\mathrm{tBu}, \mathrm{Me}}\right) \mathrm{Cu}^{\mathrm{I}} \mathrm{CO}$ in solution (Figure 3a), (1) the charge of the complex changes to give a cation, (2) the $\mathrm{Cu}-\mathrm{N}$ distances lengthen (from the computational data), and (3) the CO stretch shifts by $\sim 20 \mathrm{~cm}^{-1}$ by IR spectroscopy.[29] It is apparent that protonation reduced the electron density at copper that is available for back-bonding and leads to the observed changes in the CO stretching frequency.[29] Similarly, we predict that upon protonation of the triazolyl ring in $\left[\left(\mathrm{Ttz}^{\mathrm{tBu}, \mathrm{Me}}\right) \mathrm{Cu}^{\mathrm{II}} \mathrm{X}\right]$, where $\mathrm{X}$ is an anionic ligand (e.g. $\mathrm{Cl}^{-}$or $\left.\mathrm{NO}_{2}{ }^{-}\right)$, the amount of electron density present at the copper(II) ion should be decreased (Figure 3b). Thus, we predict that the $\mathrm{Cu}$-center should be easier to reduce upon protonation of Ttz. The copper literature shows that replacing anionic with neutral $\mathrm{N}_{3}$ donor ligands leads to significant changes in the $\mathrm{Cu}^{\mathrm{I}}-\mathrm{CO}$ stretching frequencies,[48-51] the $\mathrm{Cu}(\mathrm{I} / \mathrm{II})$ redox potential,[50] and the electronic spectra of $\mathrm{Cu}(\mathrm{II})$ complexes.[10] The key difference in our study is that we use protonation (rather than synthesis) to change the charge of the ligand. In contrast, Tp ligands do not have a remote site for binding acids, and thus they require multiple synthetic steps to modify their electronic properties, as do most organic ligands.[37] Using ligand protonation to change a metal based redox potential has been demonstrated previously with other metals (e.g. Fe, Ni) and in biological systems.[5257] 
(a) As shown in our prior work, Chem Comm. 2013, 49, 5571:

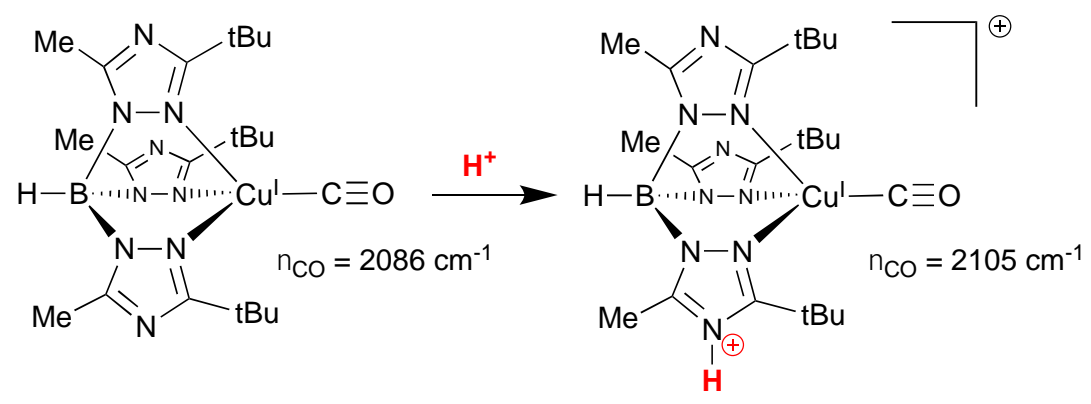

(b) This work:
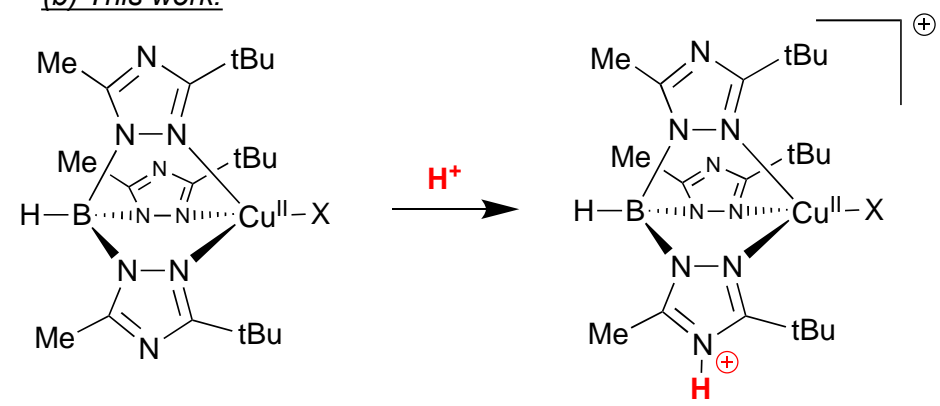

Figure 3: (a) Our prior work showed that protonation of the Ttz ligand leads to a change in the $\mathrm{CO}$ stretching frequency. Thus, the amount of electron density at copper that is available for back-bonding is sensitive to protonation of the triazole rings. (b) In our current work, the ligand protonation leads to a change in the charge of the complex that is expected to facilitate the reduction of $\mathrm{Cu}(\mathrm{II})$ to $\mathrm{Cu}(\mathrm{I})$ and alter the redox potential. Note that the $\mathrm{NH}^{+}$is in conjugation with the donor $\mathrm{N}$ atom bound to the copper ion.

Previously, our group reported the successful biomimetic reduction of nitrite to $\mathrm{NO}_{(\mathrm{g})}$ $[\mathrm{PPN}]^{+}\left[\left(\mathrm{Ttz}^{\mathrm{tBu}, \mathrm{Me}}\right) \mathrm{Cu}^{\mathrm{I}} \mathrm{NO}_{2}\right]^{-}$as a model (Figure 1).[8] We started with copper(I) (bottom of Figure 1) and performed nitrite reduction to form a stable by-product, [( $\left.\left.\mathrm{Ttz}^{\mathrm{tBu}, \mathrm{Me}}\right) \mathrm{Cu}^{\mathrm{II}}\left(\mathrm{O}_{2} \mathrm{CCH}_{3}\right)\right]$. This byproduct results from $\mathrm{Cu}$ (II) being trapped by the acetate counter-anion supplied with acetic acid as the proton source.[8] This by-product is stable and is not easily reduced in situ, and this explains why we reported stoichiometric rather than catalytic nitrite reduction. After this paper was published, we began to wonder if ligand protonation could facilitate $\mathrm{Cu}$ (II) reduction to $\mathrm{Cu}(\mathrm{I})$ and allow for a complete catalytic cycle. It has been shown that redox potential of a metal could be shifted by protonation or deprotonation of its supporting ligand.[51, 53, 54, 58] These ideas provided the motivation for the work herein.

Here, we report the electrochemical behavior of $\left(\mathrm{Ttz}^{\mathrm{tBu}, \mathrm{Me}}\right) \mathrm{CuX}(\mathbf{1}$ and $\mathbf{2})$ under both neutral and acidic conditions. Furthermore, since there is precedence for redox non-innocence in triazole rings we aimed to investigate this point.[59] Our prior study of $\mathrm{Ttz}$ complexes of $\mathrm{Cu}$ (II) (d ${ }^{9}$ ) showed by EPR that some of the unpaired electron density does delocalize on the triazole ring nitrogen atoms.[8] Thus, we performed electrochemical experiments with several related compounds, including ( $\left.\mathrm{Ttz}^{\mathrm{tBu}, \mathrm{Me}}\right) \mathrm{ZnCl}(\mathbf{3}),\left(\mathrm{Ttz}^{\mathrm{tBu}, \mathrm{Me}}\right) \mathrm{K}(\mathbf{4}),\left(\mathrm{Ttz}^{\mathrm{tBu}, \mathrm{Me}}\right) \mathrm{H}(\mathbf{5})$, and $\mathrm{Htz}^{\mathrm{tBu}, \mathrm{Me}}$ (6) 
(Figure 4). Thus, we aimed to determine whether redox non-innocence which has been described for other systems,[59-63] can be extended to Ttz ligands and complexes.
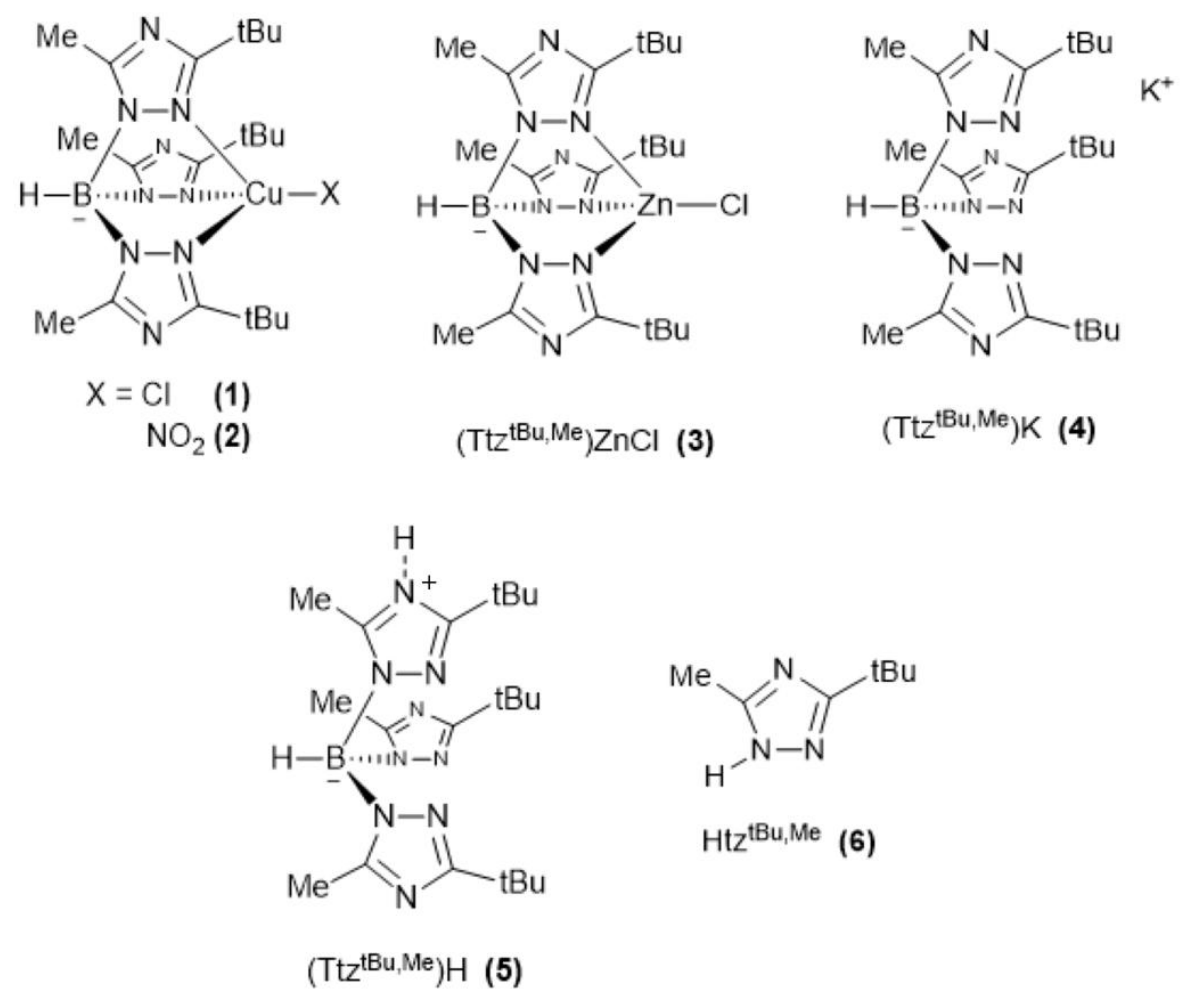

Figure 4: Structure of compounds used in this study. 


\section{Experimental}

\subsection{General: Instrumentation and Procedures.}

${ }^{1} \mathrm{H}$ and ${ }^{13} \mathrm{C}$-NMR spectra were acquired at room temperature on a Varian $300 \mathrm{MHz}$ and 500 $\mathrm{MHz}$ spectrometer, as designated and referenced to the solvent. IR spectra were recorded on a Perkin-Elmer Spectrum One Fourier-transform IR absorption spectrophotometer. Electronic spectra were recorded on Perkin Elmer Lambda $35 \mathrm{UV}$-Vis spectrometer. High-resolution mass spectrometry was performed on VG70SE double focusing, triple quadruple mass spectrometer equipped with CI ionization capability. Cyclic voltammetry was performed using a CHI760C Potentiostat.

\subsection{Materials.}

The syntheses of the complexes (1-6) in Figure $4\left[\mathrm{Htz}^{\mathrm{tBu}, \mathrm{Me}}, \mathrm{H}\left(\mathrm{Ttz}^{\mathrm{tBu}, \mathrm{Me}}\right), \mathrm{K}\left(\mathrm{Ttz}^{\mathrm{tBu}, \mathrm{Me}}\right)\right.$, $\left(\mathrm{Ttz}^{\mathrm{tBu}, \mathrm{Me}}\right) \mathrm{ZnCl},\left(\mathrm{Ttz}^{\mathrm{tBu}, \mathrm{Me}}\right) \mathrm{CuCl}$, and $\left.\left(\mathrm{Ttz}^{\mathrm{tBu}, \mathrm{Me}}\right) \mathrm{Cu}\left(\mathrm{NO}_{2}\right)\right]$ were carried out according to literature procedures (Scheme 1).[8, 31, 34, 35] Dry solvents were obtained via a Glass Counter Solvent System built by Pure Process Technology, LLC. All reagents were used as purchased and degassed under vacuum as needed. Tetrabutylammonium hexafluorophosphate $\left(\left[\mathrm{Bu}_{4} \mathrm{~N}\right]\left[\mathrm{PF}_{6}\right]\right)$ (TCI, > 98.0\%) was recrystallized from $50 \%$ mixture $\mathrm{MeOH} / \mathrm{H}_{2} \mathrm{O}$, filtered, washed with cold methanol, and dried under vacuum at $50{ }^{\circ} \mathrm{C}$ for $24 \mathrm{~h}$. Ferrocene $(\mathrm{Fc})$ (Aldrich, 98\%) was recrystallized from hexane, filtered, and further dry under vacuum. Tetrafluoroboric acid diethyl ether complex (Sigma Aldrich, 51-57\% $\mathrm{HBF}_{4}$ ), trifluroacetic acid (Sigma Aldrich, $99 \%$ ), formic acid (Sigma Aldrich, > 95\%), Bis(triphenylphosphoranylidene)ammonium nitrite [PPN] $\left[\mathrm{NO}_{2}\right]$ and $\mathrm{NaNO}_{2}$ (Sigma Aldrich) were used as received.

\subsection{Procedure for Electrochemical studies.}

Cyclic voltammetry of the $\mathrm{Ttz}^{\mathrm{tBu}, \mathrm{Me}}$ complexes were conducted in a $1.0 \mathrm{M}$ solution of $\mathrm{Bu}_{4} \mathrm{NPF}_{6}$ in dichloromethane with a glassy carbon working electrode, a Pt counter electrode, and a $\mathrm{Ag} / \mathrm{AgCl}$ reference electrode. The redox potentials are calibrated to $\mathrm{Fc} / \mathrm{Fc}^{+}$and are reported vs. SCE. The working electrodes were polished with $0.5 \mu \mathrm{m}$ alumina powder and $0.05 \mu \mathrm{m}$ alumina powder, ultra-sonicated for at least $30 \mathrm{~min}$, and rinsed with distilled water before use.

Electrochemical studied was performed under an inert atmosphere. Under neutral conditions, a desired amount of each different analyte was obtained to prepare a $6.7 \mathrm{mM}$ stock solution in dichloromethane containing $1.0 \mathrm{M}$ electrolyte $\left[\mathrm{Bu}_{4} \mathrm{~N}\right]\left[\mathrm{PF}_{6}\right]$ using volumetric flasks. Under acidic conditions (freshly prepared for each quantity of acid), a desired amount of $50 \mathrm{mM}$ acid in dichloromethane containing $1.0 \mathrm{M}$ electrolyte was added into the analyte $(2 \mathrm{~mL}, 6.7 \mathrm{mM})$ via a glass syringe. The solutions were stirred between scans. 


\section{Results and Discussion}

\subsection{Synthesis}

The complexes used in this study have been made previously (by the routes in Scheme 1) and were synthesized by known methods.[8, 31, 34, 35] These are copper and zinc complexes $\left[\left(\mathrm{Ttz}^{\mathrm{tBu}, \mathrm{Me}}\right) \mathrm{CuCl}(\mathbf{1}),\left(\mathrm{Ttz}^{\mathrm{tBu}}, \mathrm{Me}\right) \mathrm{CuNO}_{2}(\mathbf{2}),\left(\mathrm{Ttz}^{\mathrm{tBu}, \mathrm{Me}}\right) \mathrm{ZnCl}(\mathbf{3})\right]$ which allow us to contrast a redox active metal (copper) with a redox inactive metal (zinc). Furthermore, $\mathrm{K}\left(\mathrm{Ttz}^{\mathrm{tBu}, \mathrm{Me}}\right)$ (4), $\left(\mathrm{Ttz}^{\mathrm{tBu}, \mathrm{Me}}\right) \mathrm{H}(\mathbf{5})$, and $\mathrm{Htz}^{\mathrm{tBu}}$, Me $(\mathbf{6})$ allow us to probe the electrochemical behavior of the free triazole rings. We expect these triazole rings to be more electron rich when they are not coordinated to a divalent transition metal.

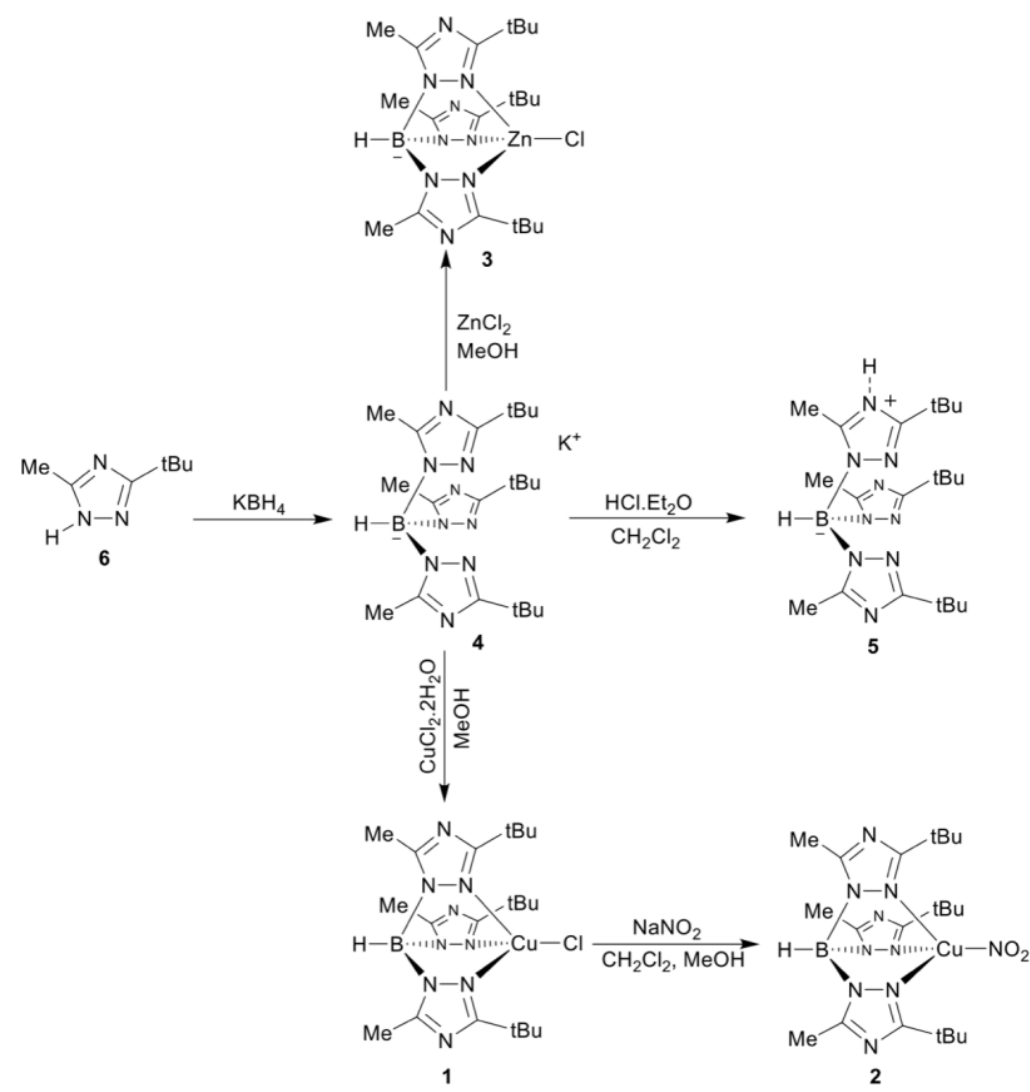

Scheme 1: Synthetic routes to compounds $\mathbf{1 - 6}$, which are known in the literature.

\subsection{Electrochemistry}

To investigate the feasibility of reduction of $\mathrm{Cu}^{\mathrm{II}}$ to $\mathrm{Cu}^{\mathrm{I}}$ in our model, we first measured the reduction potential of a non-aqueous solution with $\left(\mathrm{Ttz}^{\mathrm{tBu}, \mathrm{Me}}\right) \mathrm{Cu}^{\mathrm{II}} \mathrm{Cl}(\mathbf{1})$ as a control study since it does not contain nitrite. Under neutral conditions, reversible $\mathrm{Cu}^{\text {II }}$ to $\mathrm{Cu}^{\mathrm{I}}$ reduction processes were observed $\left(\mathrm{E}_{1 / 2}=0.27 \mathrm{~V}, \mathrm{E}_{\mathrm{pc}}=0.24 \mathrm{~V}\right.$, and $\mathrm{E}_{\mathrm{pa}}=0.31 \mathrm{~V}$ vs. SCE $)$. This is similar to a reported five coordinate $\left(\mathrm{Tp}^{\mathrm{Me}, \mathrm{Ar}}\right) \mathrm{Cu}{ }^{\mathrm{II}} \mathrm{Cl}\left(\right.$ pyrazole) complex with $\mathrm{E}_{1 / 2}=0.368 \mathrm{~V}$ for the $\mathrm{Cu}^{\mathrm{II} / \mathrm{I}}$ redox 
potential.[64] When $\mathrm{H}^{+}$(from $\mathrm{HBF}_{4} \bullet \mathrm{Et}_{2} \mathrm{O}$ ) was introduced to a solution of complex 1, new redox peaks corresponding to $\mathrm{Cu}^{\mathrm{II}}$ conversion to $\mathrm{Cu}^{\mathrm{I}}$ are detected. The reduction peaks shift more positive by $\Delta \mathrm{E}_{\mathrm{pc}}=290 \mathrm{mV}$ for 1.0 equiv. of acid (Figure 5, Table 1). Further shifts are seen $\left(\Delta \mathrm{E}_{\mathrm{pc}}=414 \mathrm{mV}\right)$ as up to 2.5 equiv. of acid are added (Figure $\left.\mathrm{S} 1\right)$. However, when 3 equiv. of $\mathrm{H}^{+}$ is added to $\mathbf{1}$, a brown precipitate was observed in the solution, suggesting that decomposition has occurred (Figure S1). These results confirm that, with (1), acid does shift the reduction of the $\mathrm{Cu}(\mathrm{II})$ to $\mathrm{Cu}(\mathrm{I})$, and the shift is in the expected direction (more positive) so long as excess acid is avoided.

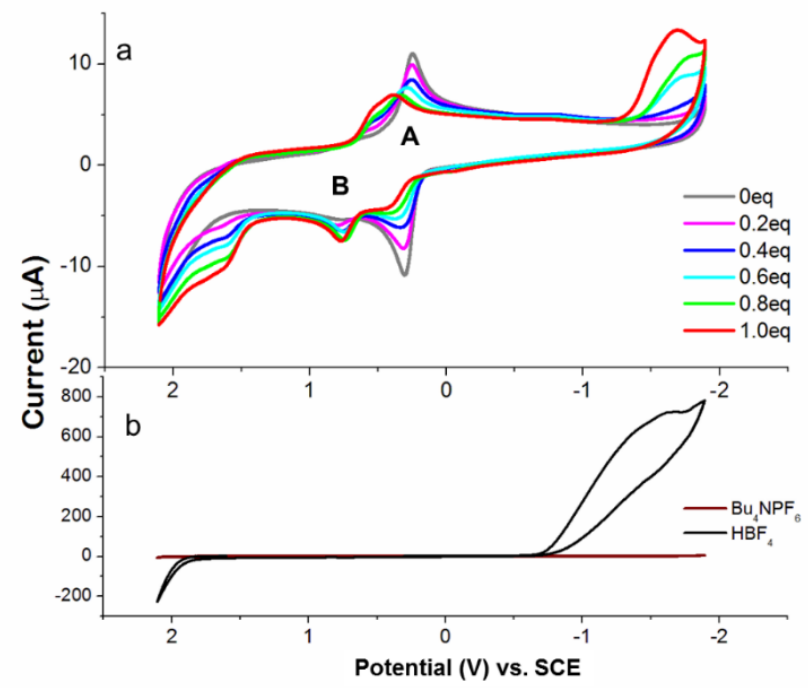

Figure 5: Cyclic voltammogram of $\mathrm{Ttz}^{\mathrm{tBu}, \mathrm{Me}} \mathrm{CuCl}(\mathbf{1})$ in $\mathrm{CH}_{2} \mathrm{Cl}_{2}$ containing $1.0 \mathrm{M}\left[\mathrm{Bu}_{4} \mathrm{~N}\right]\left[\mathrm{PF}_{6}\right]$ as a supporting electrolyte, at scan rate of $100 \mathrm{mV} / \mathrm{s}$, glassy carbon working electrode. (a) Stacked voltammograms of the acid study up to 1.0 equivalent. (b) Voltammogram of $\mathrm{HBF}_{4} . \mathrm{Et}_{2} \mathrm{O}$ in $1.0 \mathrm{M}\left[\mathrm{Bu}_{4} \mathrm{~N}\right]\left[\mathrm{PF}_{6}\right]$ supporting electrolyte.

\begin{tabular}{l|ll|ll|ll}
\hline $\mathrm{HBF}_{4}$ & $\mathrm{E}_{\mathrm{pc}}(\mathrm{V})$ & & $\mathrm{E}_{\mathrm{pa}}(\mathrm{V})$ & & $\mathrm{E}_{1 / 2}(\mathrm{~V})$ & \\
\cline { 2 - 7 } (equivalent) & $\mathrm{A}$ & $\mathrm{B}$ & $\mathrm{A}$ & $\mathrm{B}$ & $\mathrm{A}$ & $\mathrm{B}$ \\
\hline \hline 0 & 0.24 & - & 0.31 & - & 0.27 & - \\
0.2 & 0.25 & 0.62 & 0.31 & 0.81 & 0.28 & - \\
0.4 & 0.27 & 0.51 & 0.34 & 0.78 & 0.31 & - \\
0.6 & 0.29 & 0.56 & 0.36 & 0.76 & 0.33 & - \\
0.8 & 0.34 & 0.52 & 0.39 & 0.73 & 0.36 & - \\
1.0 & 0.39 & 0.53 & 0.43 & 0.78 & 0.41 & - \\
\hline
\end{tabular}

Table 1. Summary of redox potential of complex $\mathrm{Ttz}^{\mathrm{tBu}, \mathrm{Me}} \mathrm{CuCl}$ (1) up to 1 mole equivalent of acid collected in $1.0 \mathrm{M}\left[\mathrm{Bu}_{4} \mathrm{~N}\right]\left[\mathrm{PF}_{6}\right]$ as a supporting electrolyte in $\mathrm{CH}_{2} \mathrm{Cl}_{2}$. Potential are vs. SCE $\left(\mathrm{Fc} / \mathrm{Fc}^{+}\right.$couple in $\left.\mathrm{CH}_{2} \mathrm{Cl}_{2}, \mathrm{E}_{1 / 2}=+0.46 \mathrm{~V}\right)$ 
We postulated that the reduction potential from $\mathrm{Cu}^{\mathrm{II}}$ to $\mathrm{Cu}^{\mathrm{I}}$ of $\left(\mathrm{Ttz}^{\mathrm{tBu}, \mathrm{Me}}\right) \mathrm{Cu}^{\mathrm{II}} \mathrm{NO}_{2}$ (2) should similarly be sensitive to the addition of acid. The cyclic voltammogram of $\left(\mathrm{Ttz}^{\mathrm{tBu}, \mathrm{Me}}\right) \mathrm{Cu}(\mathrm{II}) \mathrm{NO}_{2}$ (2) with varied amounts of $\mathrm{HBF}_{4}$ and the resulting electrochemical data are shown in Figure 6 and Table 2, respectively. Under neutral conditions in $\mathrm{CH}_{2} \mathrm{Cl}_{2}$, a reduction from $\mathrm{Cu}^{\mathrm{II}}$ to $\mathrm{Cu}^{\mathrm{I}}$ is observed at $\mathrm{E}_{1 / 2}$ at $0.18 \mathrm{~V}\left(\mathrm{E}_{\mathrm{pc}}=0.101 \mathrm{~V}\right.$ and $\mathrm{E}_{\mathrm{pa}}=0.253 \mathrm{~V}$ vs. SCE $)$. For comparison, Hsu et al. observed an irreversible $\mathrm{E}_{\mathrm{pa}}=0.08 \mathrm{~V}$ for $\mathrm{Cu}^{\mathrm{I}}$ oxidation with $\left[\mathrm{Tp}^{\mathrm{Me}, \mathrm{Me}} \mathrm{Cu}^{\mathrm{I}}\left(\mathrm{NO}_{2}\right)\right]^{-}$.[27] The difference here is due to $\mathrm{Ttz}^{\mathrm{tBu}, \mathrm{Me}}$ being a weaker electron donor vs. $\mathrm{Tp}^{\mathrm{Me}, \mathrm{Me}}$.[30] Comparing to other $(\mathrm{L}) \mathrm{Cu}^{\mathrm{II}} \mathrm{NO}_{2}$ complexes in the literature, our $\mathrm{Cu}^{\mathrm{II} / \mathrm{I}}$ redox potential is much higher than the values for $\mathrm{L}_{1}$ and $\mathrm{L}_{2}$ complexes described in the introduction $\left(\mathrm{E}_{1 / 2}=-0.027 \mathrm{~V}\right.$ and $-0.375 \mathrm{~V}$ vs. SCE with $\mathrm{L}_{1}$ and $\mathrm{L}_{2}$, respectively) which makes sense because these ligands are stronger donors than $\mathrm{Ttz}^{\mathrm{tBu}, \mathrm{Me}}$. [26-28]

Notice that the reduction potential we observed for 2 at $0.18 \mathrm{~V}$ is much higher than the value we previously reported for $\mathrm{E}_{\mathrm{pc}}$ of $-1.45 \mathrm{~V}$ (vs. a non-aqueous $\mathrm{Ag} / \mathrm{Ag}\left(\mathrm{ClO}_{4}\right)$, or $-1.15 \mathrm{~V}$ vs. SCE reference electrode in $\mathrm{CH}_{2} \mathrm{Cl}_{2}$ ). $[8,65] \mathrm{We}$ conclude that this reduction potential was in error due to the high resistivity of the solution $\left(\mathrm{CH}_{2} \mathrm{Cl}_{2}\right)$ which was previously not accounted for using the Ohmic drop (iR) method. Also, previously we used 0.1 M of electrolyte.[8] Here we corrected this value by increasing the electrolyte concentration to $1.0 \mathrm{M}$ to improve solution conductivity and we corrected for the solution resistivity during each experiment.

Upon introducing acid $\left(\mathrm{HBF}_{4} \cdot \mathrm{Et}_{2} \mathrm{O}\right)$ into the solution of 2, the reduction peak is gradually shifted to more negative potential (Figure 6a), as summarized in Table 2. The direction of this shift was unexpected and contrasts with the electrochemical behavior of $\mathbf{1}$ in acid. Furthermore, with 2 and $\mathrm{HBF}_{4} \cdot \mathrm{Et}_{2} \mathrm{O}$, additional irreversible reduction peaks at $\mathrm{E}_{\mathrm{pc}}=-0.49 \mathrm{~V}$ and $\mathrm{E}_{\mathrm{pc}}=-0.73 \mathrm{~V}$ were also observed at 0.8 and 1.0 equivalent of $\mathrm{H}^{+}$, respectively (Figure 6b). Control experiments showed that these changes are not induced by the addition of ether. Different acids including trifluoroacetic acid (TFA) and formic acid (FA) were added to 2 to see if the direction of the shift in reduction potentials would vary with the acid used; however, the overall result was similar to that seen with $\mathrm{HBF}_{4} \cdot \mathrm{Et}_{2} \mathrm{O}$ (Figure S3-S6). 


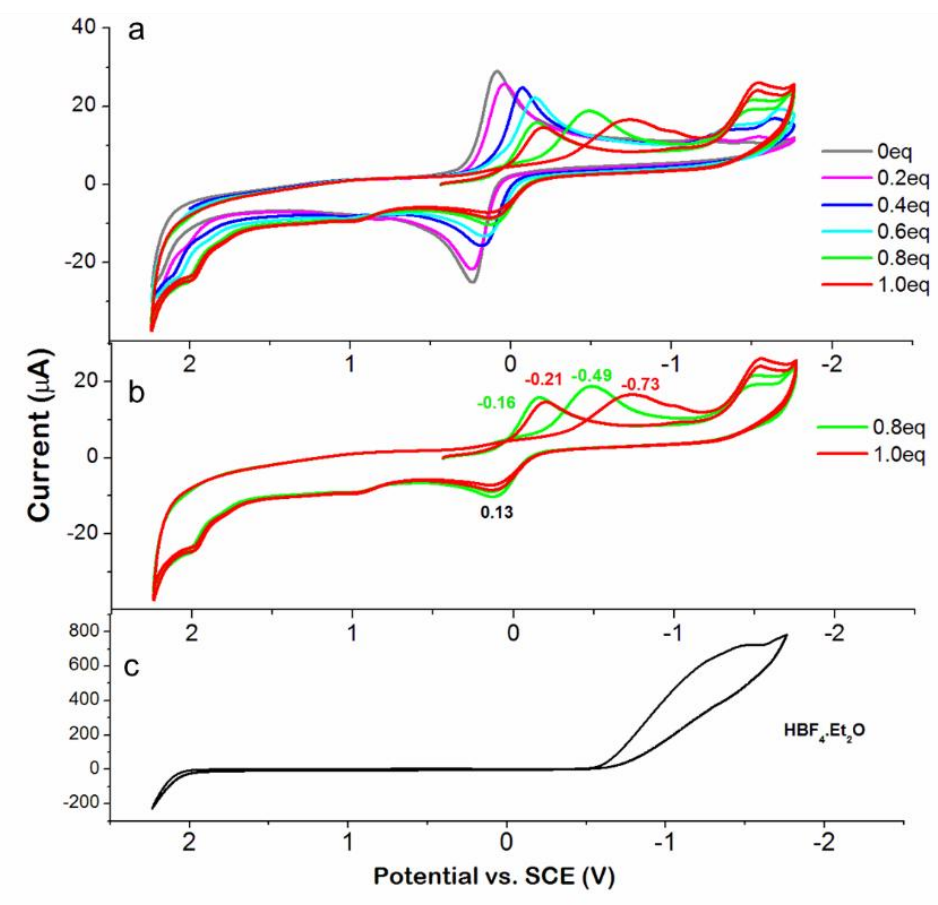

Figure 6. Cyclic voltammogram of 2 in $\mathrm{CH}_{2} \mathrm{Cl}_{2}$ containing $1.0 \mathrm{M}\left[\mathrm{Bu}_{4} \mathrm{~N}\right]\left[\mathrm{PF}_{6}\right]$ as a supporting electrolyte, at scan rate of $100 \mathrm{mV} / \mathrm{s}$, at glassy carbon working electrode. (a) Stacked voltammogram of the acid studies up to 1.0 equivalent. (b) Isolation of the voltammograms at 0.8 and 1.0 equivalent. (c) Voltammogram of $\mathrm{HBF}_{4} \cdot \mathrm{Et}_{2} \mathrm{O}$ in $1 \mathrm{M}\left[\mathrm{Bu}_{4} \mathrm{~N}\right]\left[\mathrm{PF}_{6}\right]$ supporting electrolyte.

\begin{tabular}{c|cc|cc}
\hline \multirow{2}{*}{$\begin{array}{c}\mathrm{HBF}_{4} \\
\text { (equivalent) }\end{array}$} & \multicolumn{2}{|c|}{$\mathrm{E}_{\mathrm{pc}}(\mathrm{V})$} & \multicolumn{3}{c}{$\mathrm{E}_{\mathrm{pa}}(\mathrm{V})$} & \\
\cline { 2 - 5 } & $\mathrm{A}$ & $\mathrm{B}$ & $\mathrm{A}$ & $\mathrm{B}$ \\
\hline \hline 0 & 0.101 & - & 0.253 & - \\
0.2 & 0.0325 & - & 0.253 & - \\
0.4 & -0.0796 & - & 0.194 & - \\
0.6 & -0.149 & - & 0.171 & - \\
0.8 & -0.16 & -0.493 & 0.131 & - \\
1 & -0.208 & -0.734 & 0.131 & - \\
\hline
\end{tabular}

Table 2. Electrochemical data for complex 2 collected in $1.0 \mathrm{M}\left[\mathrm{Bu}_{4} \mathrm{~N}\right]\left[\mathrm{PF}_{6}\right]$ as a supporting electrolyte in $\mathrm{CH}_{2} \mathrm{Cl}_{2}$. Potentials are vs. $\mathrm{SCE}\left(\mathrm{Fc} / \mathrm{Fc}^{+}\right.$couple in $\left.\mathrm{CH}_{2} \mathrm{Cl}_{2}, \mathrm{E}_{1 / 2}=+0.46 \mathrm{~V}\right)$.

There are a few possible explanations for the unexpected changes in the redox potentials of 2 with acid added. One possibility is that the irreversible cathodic waves could be due to the reduction potential of $\mathrm{H}\left(\mathrm{Ttz}^{\mathrm{tBu}, \mathrm{Me}}\right)(\mathbf{5})$ generated in situ upon addition of acid. This would only occur if complex 2 had its Ttz ligand de-coordinate from the $\mathrm{Cu}(\mathrm{II})$ with acid present. To investigate this hypothesis, the reduction of $\mathrm{H}\left(\mathrm{Ttz}^{\mathrm{tBu}, \mathrm{Me}}\right)$ was studied using the same conditions and these CVs showed no redox activity within the region of interest (Figure S9 and S10). Thus, the reduction of $\mathrm{H}\left(\mathrm{Ttz}^{\mathrm{tBu}, \mathrm{Me}}\right)(\mathbf{5})$ is not involved and we have no evidence of $\mathbf{5}$ forming from 2 here. 
A second possible reason is that the shifting reduction potential in Figure 6 is due to the reduction of $\left[\left(\mathrm{Ttz}^{\mathrm{tBu}, \mathrm{Me}}\right) \mathrm{Cu}^{\mathrm{I}} \mathrm{NO}_{2}\right]^{-}$generated in situ to produce $\mathrm{NO}_{(\mathrm{g})}$ when enough acid is added. We note that in prior studies we demonstrated that synthesized $\left[\left(\mathrm{Ttz}^{\mathrm{tBu}, \mathrm{Me}}\right) \mathrm{Cu}^{\mathrm{I}} \mathrm{NO}_{2}\right]^{-}$can reduce nitrite to NO,[8] so it seems likely that the same molecule generated in situ would also reduce nitrite. However, efforts to observe NO in solution here by in situ IR spectroscopy have not been successful, but the quantities formed by the electrochemical reduction may be below the detection limit. To probe this hypothesis, bis(triphenylphosphoranyledene)ammonium nitrite $\left([\mathrm{PPN}]\left[\mathrm{NO}_{2}\right]\right)$ was used to observed whether the second reduction wave is scan rate dependent in the presence of excess nitrite. A control experiment was also carried out with only the $[\mathrm{PPN}]\left[\mathrm{NO}_{2}\right]$ salt and the acid. The reduction potentials of free $\mathrm{NO}_{2}{ }^{-}$under both neutral and acidic conditions are shown in Figures 7 and S8. In this study, the reduction of nitrite of $[\mathrm{PPN}]\left[\mathrm{NO}_{2}\right]$ salt is observed at $\mathrm{E}_{\mathrm{pc}}=-0.46 \mathrm{~V}$ (tentatively assigned) under neutral conditions, which is similar to the reduction peak at $-0.49 \mathrm{~V}$ observed for $\left(\mathrm{Ttz}^{\mathrm{tBu}, \mathrm{Me}}\right) \mathrm{CuNO}_{2}(2)$ in the presence of 0.8 equiv. of acid. Similarly, when adding $\mathrm{HBF}_{4}$ up to 1.0 (eq) to the $[\mathrm{PPN}]\left[\mathrm{NO}_{2}\right]$ solution, two reduction potentials observed at $\mathrm{E}_{\mathrm{pc} 1}=-0.48 \mathrm{~V}$ (already explained above) and $\mathrm{E}_{\mathrm{pc} 2}=-0.72 \mathrm{~V}$. The second reduction at $\mathrm{E}_{\mathrm{pc} 2}=-0.72 \mathrm{~V}$ (for the $[\mathrm{PPN}]\left[\mathrm{NO}_{2}\right]$ salt) is similar to the reduction peak $\left(\mathrm{E}_{\mathrm{pc}}=-0.73\right.$ $\mathrm{V})$ for complex 2 protonated with 1 equiv. of acid. These results suggest that the new reduction peaks observed for $\mathbf{2}$ in the presence of acid are due to free nitrite being reduced in solution. The anodic peaks on the oxidation side of the CV in Figure 7 seem to be more complex and may be due to the oxidation of the aromatic rings of the bis(triphenylphospine)iminium cation.

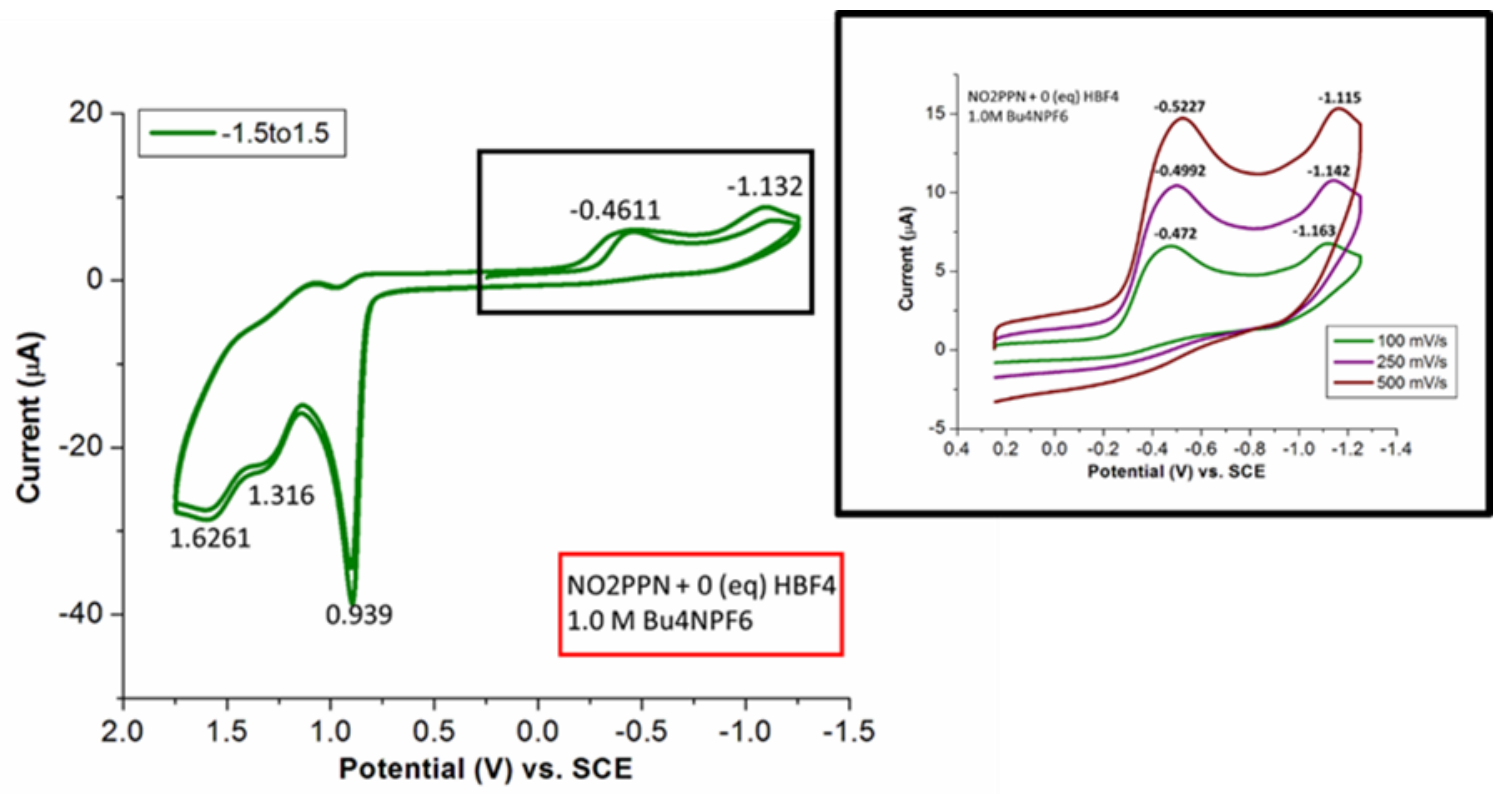

Figure 7: Voltammogram of $\mathrm{PPNNO}_{2}$ salt at 0 acid equivalent taken from -1.5 to $1.5 \mathrm{~V}$ potential window at $100 \mathrm{mV} / \mathrm{s}$ (left). Taken at shorter window (-1.5 to $0 \mathrm{~V}$ ) at various scan rate; 100, 250, and $500 \mathrm{mV} / \mathrm{s}$ (on the right, in the box). 
Other electrochemical studies were aimed at determining whether (or not) the Ttz ligand is redox non-innocent.[59] Studies in the literature by Wieghardt and others have shown aromatic ligands can be redox active in some metal complexes.[60-63] Specifically, for Ttz, we wondered if reduction (with $\mathbf{1}$ or $\mathbf{2}$, or their protonated analogs) may occur on the triazole ring rather than on the metal. Studies were conducted using a series of compounds including a simple triazole ring $\mathrm{Htz}^{\mathrm{tBu}, \mathrm{Me}}(\mathbf{6})$, the potassium salt of the ligand $\mathrm{K}\left(\mathrm{Ttz}^{\mathrm{tBu}, \mathrm{Me}}\right)(\mathbf{4})$, and a redox inactive metal $\left(\mathrm{Ttz}^{\mathrm{tBu}, \mathrm{Me}}\right) \mathrm{ZnCl}(3)$. Our rationale for comparing monovalent and divalent metal complexes with the free triazole ring was that metal coordination might make the triazole ring more electron poor and more vulnerable to reduction. No reduction peaks were observed in all three cases under both neutral and acidic conditions. Under acidic conditions, a reduction peak was observed near $2.0 \mathrm{~V}$ due to the reduction of $\mathrm{H}^{+}$to $\mathrm{H}_{2(\mathrm{~g})}$ (Figure $\mathrm{S} 11-\mathrm{S} 13$ ). These studies have shown that the $\mathrm{Ttz}^{\mathrm{tBu}, \mathrm{Me}}$ ligand is redox inactive under these conditions.

\subsection{UV-Vis Spectroscopy}

We aimed to gather spectroscopic data on how protonation influences the structure of $\mathbf{1}$ and 2. The UV-vis spectrum of 1 under neutral conditions shows two absorbance bands at $312 \mathrm{~nm}(\varepsilon$ $\left.\sim 2703 \mathrm{M}^{-1} \mathrm{~cm}^{-1}\right)$ and ligand to metal charge transfer (LMCT) band at $392 \mathrm{~nm}\left(\varepsilon \sim 1916 \mathrm{M}^{-1} \mathrm{~cm}^{-1}\right)$ (Figure S2). The LMCT band shifted toward a higher wavelength by $11 \mathrm{~nm}$ upon increasing the concentration of acid (Figure 9). This experiment shows that complex $\mathbf{1}$ is stable towards protonation and the ligand to metal charge transfer band decreased in energy upon increasing acid concentration, which is consistent with the electrochemical experiments.

The UV-vis of 2 show $\pi$ to $\pi^{*}$ band at $310 \mathrm{~nm}\left(\varepsilon=2720 \mathrm{M}^{-1} \mathrm{~cm}^{-1}\right)$ and a d-d band observed at $800 \mathrm{~nm}$ (Figure S7). This $\pi$ to $\pi^{*}$ and d-d transition show a shift to higher energy (by $3 \mathrm{~nm}$ ) upon protonation with up to 1.0 equivalent of $\mathrm{HBF}_{4} \cdot \mathrm{Et}_{2} \mathrm{O}$ (Figure 10). Thus, complex 2 shows no significant change in the UV-Vis upon the addition of acid. This suggests that the changes in the electrochemical reduction potentials observed for $\mathbf{2}$ upon adding acid have more to do with the decomposition of $\mathbf{2}$ at reducing potentials with acid (to produce free nitrite). The changes observed are not due to the impact of acid alone. 


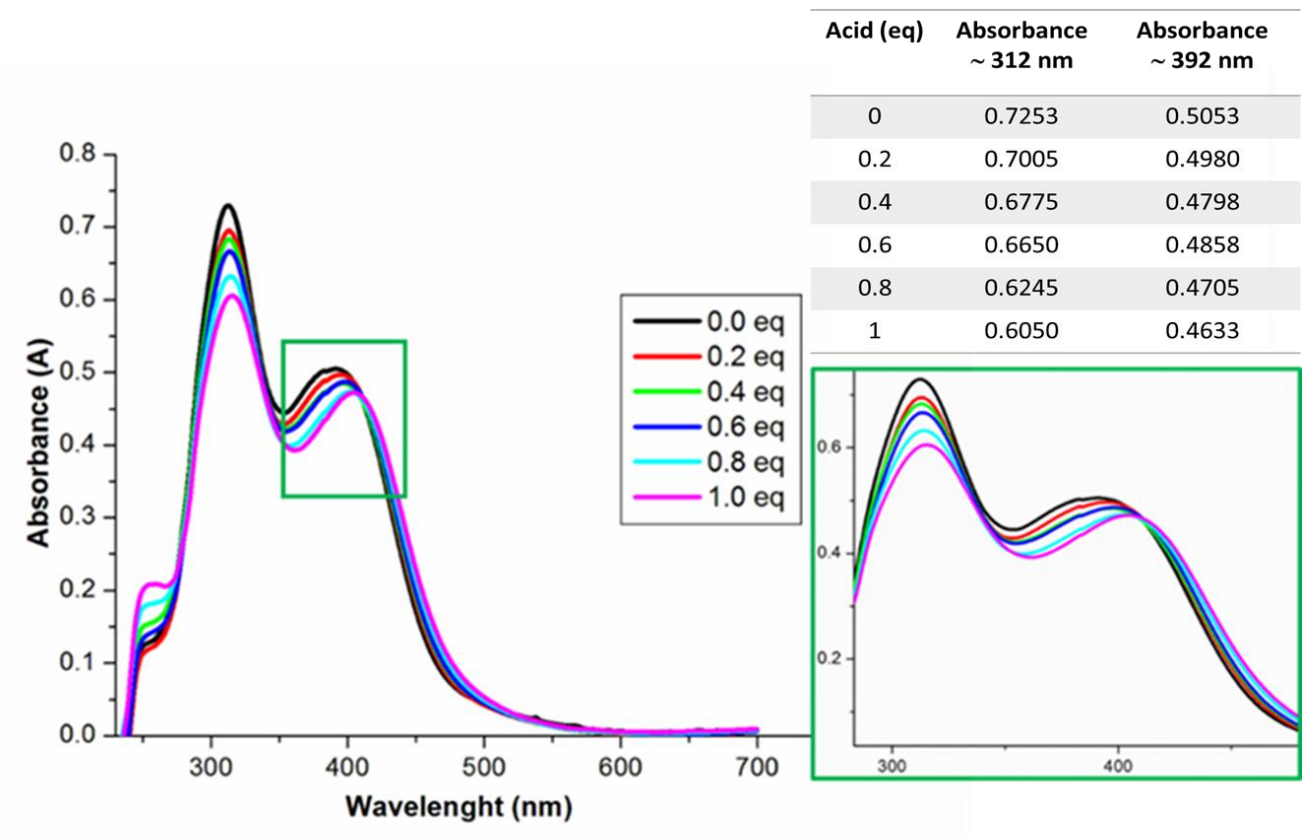

Figure 9: $\mathrm{UV}$-vis spectrum of protonated $\mathrm{Ttz}^{\mathrm{tBuMe}} \mathrm{CuCl}$ with $\mathrm{HBF}_{4}$ up to 1.0 equivalent. The LMCT band at $392 \mathrm{~nm}$ gradually shifted about $11 \mathrm{~nm}$ to lower energy as concentration of acid is increased.

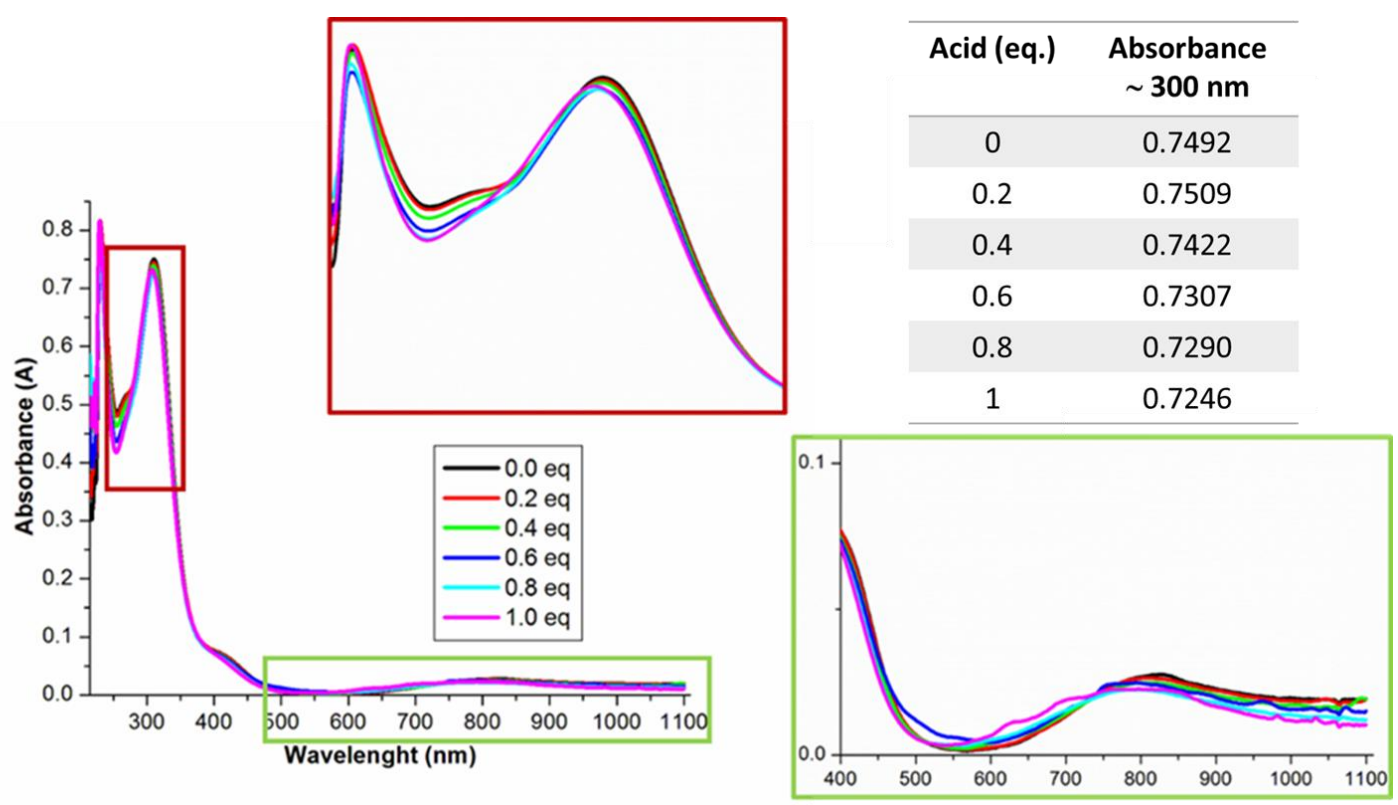

Figure 10: UV-vis spectrum in $\mathrm{CH}_{2} \mathrm{Cl}_{2}$ of protonated $\mathrm{Ttz}^{\mathrm{tBuMe}} \mathrm{CuNO}_{2}$ with $\mathrm{HBF}_{4}$ up to 1.0 equivalent. The $\pi$ to $\pi^{*}$ band observed at $310 \mathrm{~nm}$ and d-d observed around $800 \mathrm{~nm}$ which both shows slight shifted that are negligible. 


\section{Conclusions}

Electrochemistry studies of a series of tris(triazolyl)borate ligands and metal complexes were carried out under both in neutral and acidic conditions. A positive shift in the redox potential for $\left(\mathrm{Ttz}^{\mathrm{tBu}, \mathrm{Me}}\right) \mathrm{CuCl}$ (1) complex was observed and suggests that the protonation of the complex facilitates reduction, presumably due to the resulting positive charge on the complex and less electron density being donated towards the copper. In contrast, the redox behavior of $\left(\mathrm{Ttz}^{\mathrm{tBu}, \mathrm{Me}}\right) \mathrm{CuNO}_{2}(2)$ does not obey this same trend and is unexpected. It appears that complex 2 undergoes nitrite loss under reducing conditions in the presence of acid. The $\mathrm{CV}$ behavior matches that of free nitrite. We have also learned that Ttz ligands are not redox active under the conditions we have studied using both free ligands and metal complexes under neutral and acidic conditions.

Thus, due to the sensitive nature of complex 2, it appears that it was not possible to tune the redox potential with $\mathrm{H}^{+}$, as we were able to do with $\mathbf{1}$. Therefore, catalytic schemes towards nitrite reduction (as in Figure 1) are unlikely to be achieved by using $\mathrm{H}^{+}$to alter the redox potential in Ttz copper complexes. However, the concept of using protonation to tune redox potential may prove useful with other appropriate $\mathrm{CuNiR}$ models. 
Acknowledgements. We thank the US National Science Foundation (NSF) CAREER program (grants CHE-0846383 and CHE-1360802 to E. T. P. and her group) for past support; NSF EPSCoR Track 2 Seed Grant to ETP for support during 2016 (PI N. Hammer, Grant OIA1539035); Drexel University; and the University of Alabama for generous financial support. We thank Shanlin Pan and his group for assistance with electrochemistry experiments. We thank Nicolai Lehnert and Nathan Szymczak for helpful discussions. Finally, we thank the members of the Papish group, especially Nicole S. Chambers and Deidra L. Gerlach, for preliminary experiments, assistance, and suggestions.

Appendix A. Supplementary data. Supplementary data associated with this article can be found in the online version, at http://dx.doi.org/\#\#\# 


\section{References}

[1] I. Bertini, H.B. Gray, E.I. Stiefel, J.S. Valentine, Biological Inorganic Chemistry, University Science Books, Sausalito, CA, 2007.

[2] E.I. Tocheva, F.I. Rosell, A.G. Mauk, M.E.P. Murphy, Science, 304 (2004) 867-870.

[3] A.C. Merkle, N. Lehnert, Dalton Trans., (2012) 3355-3368.

[4] M.F. Anjum, T.M. Stevanin, R.C. Read, J.W.B. Moir, J Bacteriol, 184 (2002) 2987-2993.

[5] S. Suzuki, K. Kataoka, K. Yamaguchi, T. Inoue, Y. Kai, Coord Chem Rev. , 190-192 (1999) 245265.

[6] N. Castiglione, S. Rinaldo, G. Giardina, V. Stelitano, F. Cutruzzolà, Antioxid. Redox Signaling, 17 (2012) 684-716.

[7] M. Gennari, L. Marchio, Curr. Bioact. Compd., 5 (2009) 244-263.

[8] M. Kumar, N.A. Dixon, A.C. Merkle, M. Zeller, N. Lehnert, E.T. Papish, Inorg. Chem., 51 (2012) 7004-7006.

[9] M. Kujime, C. Izumi, M. Tomura, M. Hada, H. Fujii, J. Am. Chem. Soc., 130 (2008) 6088-6098.

[10] N. Lehnert, U. Cornelissen, F. Neese, T. Ono, Y. Noguchi, K. Okamoto, K. Fujisawa, Inorg. Chem., 46 (2007) 3916-3933.

[11] C.M. Moore, N.K. Szymczak, Chem. Sci., 6 (2015) 3373-3377.

[12] D. Maiti, D.-H. Lee, A.A. Narducci Sarjeant, M.Y.M. Pau, E.I. Solomon, K. Gaoutchenova, J.

Sundermeyer, K.D. Karlin, J. Am. Chem. Soc., 130 (2008) 6700-6701.

[13] J.J. Scepaniak, G. Wu, T.W. Hayton, Dalton Trans., 41 (2012) 7859-7861.

[14] S.L. Saraf, A. Miłaczewska, T. Borowski, C.D. James, D.L. Tierney, M. Popova, A.M. Arif, L.M.

Berreau, Inorg. Chem., 55 (2016) 6916-6928.

[15] C.J. Allpress, A. Miłaczewska, T. Borowski, J.R. Bennett, D.L. Tierney, A.M. Arif, L.M. Berreau, J. Am. Chem. Soc., 136 (2014) 7821-7824.

[16] M.M. Kimani, D. Watts, L.A. Graham, D. Rabinovich, G.P.A. Yap, J.L. Brumaghim, Dalton Trans., 44 (2015) 16313-16324.

[17] R.C. Maji, S.K. Barman, S. Roy, S.K. Chatterjee, F.L. Bowles, M.M. Olmstead, A.K. Patra, Inorg. Chem., 52 (2013) 11084-11095.

[18] W.B. Tolman, Adv. Chem. Ser., 246 (1995) 195-217.

[19] C.E. Ruggiero, S.M. Carrier, W.B. Tolman, Angew. Chem., 106 (1994) 917-919 (See also Angew. Chem., Int. Ed. Engl., 1994, 1933(1998), 1895-1997).

[20] S.M. Carrier, C.E. Ruggiero, R.P. Houser, W.B. Tolman, Inorg. Chem., 32 (1993) 4889-4899.

[21] N. Kitajima, K. Fujisawa, Y. Morooka, J. Am. Chem. Soc., 112 (1990) 3210-3212.

[22] X. Kou, H.V.R. Dias, Dalton Trans., (2009) 7529-7536.

[23] M.A. Mairena, J. Urbano, J. Carbajo, J.J. Maraver, E. Álvarez, M.M. Díaz-Requejo, P.J. Pérez, Inorg. Chem., 46 (2007) 7428-7435.

[24] L. Metteau, S. Parsons, J.C. Mareque-Rivas, Inorg. Chem., 45 (2006) 6601-6603.

[25] J.C. Mareque-Rivas, S.L. Hinchley, L. Metteau, S. Parsons, Dalton Trans., (2006) 2316-2322.

[26] J.G. Woollard-Shore, J.P. Holland, M.W. Jones, J.R. Dilworth, Dalton Trans., 39 (2010) 1576-1585.

[27] S.C.N. Hsu, Y.-L. Chang, W.-J. Chuang, H.-Y. Chen, I.J. Lin, M.Y. Chiang, C.-L. Kao, H.-Y. Chen, Inorg. Chem., 51 (2012) 9297-9308.

[28] K. Fujisawa, T. Ono, Y. Ishikawa, N. Amir, Y. Miyashita, K.-I. Okamoto, N. Lehnert, Inorg. Chem., 45 (2006) 1698-1713.

[29] N.A. Dixon, A.B. McQuarters, J.S. Kraus, J.B. Soffer, N. Lehnert, R. Schweitzer-Stenner, E.T.

Papish, Chem. Commun., (2013) 5571-5573.

[30] E.T. Papish, T.M. Donahue, K.R. Wells, G.P.A. Yap, Dalton Trans., (2008) 2923-2925.

[31] M. Kumar, E.T. Papish, M. Zeller, A.D. Hunter, Dalton Trans., 40 (2011) 7517-7533.

[32] S.R. Gardner, E.T. Papish, W.H. Monillas, G.P.A. Yap, J. Inorg. Biochem., 102 (2008) 2179-2183.

[33] S. Siek, N.A. Dixon, M. Kumar, J.S. Kraus, K.R. Wells, B.W. Rowe, S.P. Kelley, M. Zeller, G.P.A.

Yap, E.T. Papish, Eur. J. Inorg. Chem., (2016) 2495-2507. 
[34] F.E. Jernigan, III, N.A. Sieracki, M.T. Taylor, A.S. Jenkins, S.E. Engel, B.W. Rowe, F.A. Jove, G.P.A. Yap, E.T. Papish, G.M. Ferrence, Inorg. Chem., 46 (2007) 360-362.

[35] J.L. Bongiovanni, B.W. Rowe, P.T. Fadden, M.T. Taylor, K.R. Wells, M. Kumar, E.T. Papish, G.P.A. Yap, M. Zeller, Inorg. Chim. Acta, 363 (2010) 2163-2170.

[36] M. Kumar, E.T. Papish, M. Zeller, A.D. Hunter, Dalton Trans., 39 (2010) 59-61.

[37] E.T. Papish, N.A. Dixon, M. Kumar, Struct. Bonding, 160 (2014) 115-150.

[38] S. Trofimenko, Scorpionates: Polypyrazolylborate Ligands and Their Coordination Chemistry,

World Scientific Publishing Company, 1999.

[39] S. Trofimenko, Chem. Rev., 93 (1993) 943-980.

[40] C. Santini, M. Pellei, G.G. Lobbia, G. Papini, Mini-Reviews in Organic Chemistry, 7 (2010) 84-124.

[41] N. Kitajima, W.B. Tolman, Prog. Inorg. Chem., 43 (1995) 419-531.

[42] J.L. Schneider, S.M. Carrier, C.E. Ruggiero, V.G. Young, Jr., W.B. Tolman, J. Am. Chem. Soc., 120 (1998) 11408-11418.

[43] G. Parkin, Adv. Inorg. Chem., 42 (1995) 291-393.

[44] S. Hikichi, T. Ogihara, K. Fujisawa, N. Kitajima, M. Akita, Y. Moro-oka, Inorg. Chem., 36 (1997) 4539-4547.

[45] D.D. Wick, K.I. Goldberg, J. Am. Chem. Soc., 119 (1997) 10235-10236.

[46] Y. Alvarado, O. Boutry, E. Gutierrez, A. Monge, M.C. Nicasio, M.L. Poveda, P.J. Perez, C. Ruiz, C. Bianchini, E. Carmona, Chem. - Eur. J., 3 (1997) 860-873.

[47] S. Trofimenko, J. Am. Chem. Soc., 89 (1967) 3170-3177.

[48] K. Fujisawa, A. Tateda, Y. Miyashita, K.-i. Okamoto, F. Paulat, V.K.K. Praneeth, A. Merkle, N.

Lehnert, J. Am. Chem. Soc., 130 (2008) 1205-1213.

[49] K. Fujisawa, Y. Noguchi, Y. Miyashita, K. Okamoto, N. Lehnert, Inorg. Chem., 46 (2007) 10607-

10623.

[50] K. Fujisawa, T. Ono, Y. Ishikawa, N. Amir, Y. Miyashita, K.-i. Okamoto, N. Lehnert, Inorg. Chem., 45 (2006) 1698-1713.

[51] C.S. Letko, T.B. Rauchfuss, X. Zhou, D.L. Gray, Inorg. Chem., 51 (2012) 4511-4520.

[52] A. Kayal, T.B. Rauchfuss, Inorg. Chem., 42 (2003) 5046-5048.

[53] M.E. Carroll, B.E. Barton, T.B. Rauchfuss, P.J. Carroll, J. Am. Chem. Soc., 134 (2012) $18843-$

18852.

[54] M.E. Carroll, B.E. Barton, D.L. Gray, A.E. Mack, T.B. Rauchfuss, Inorg. Chem., 50 (2011) 9554-

9563.

[55] M. O’Hagan, W.J. Shaw, S. Raugei, S. Chen, J.Y. Yang, U.J. Kilgore, D.L. Dubois, R.M. Bullock, J. Am. Chem. Soc., 133 (2011) 14301-14312.

[56] J.Y. Yang, R.M. Bullock, W.J. Shaw, B. Twamley, K. Fraze, M.R. DuBois, D.L. DuBois, J. Am.

Chem. Soc., 131 (2009) 5935-5945.

[57] M. Rakowski DuBois, D.L. DuBois, Chem. Soc. Rev., 38 (2009) 62-72.

[58] J. DePasquale, I. Nieto, L.E. Reuther, C.J. Herbst-Gervasoni, J.J. Paul, V. Mochalin, M. Zeller, C.M.

Thomas, A.W. Addison, E.T. Papish, Inorg. Chem., 52 (2013) 9175-9183.

[59] S.V. Lokesh, A.K. Satpati, B.S. Sherigara, Open Electrochem. J., 2 (2010) 15-21.

[60] K. Ray, T. Petrenko, K. Wieghardt, F. Neese, Dalton Trans., (2007) 1552-1566.

[61] B. De Bruin, E. Bill, E. Bothe, T. Weyhermueller, K. Wieghardt, Inorg. Chem., 39 (2000) 2936-

2947.

[62] C.C. Scarborough, K. Wieghardt, Inorg. Chem., 50 (2011) 9773-9793.

[63] C.C. Scarborough, S. Sproules, T. Weyhermüller, S. DeBeer, K. Wieghardt, Inorg. Chem., 50 (2011) 12446-12462.

[64] Y. Deng, T.-Z. Ding, Y. Li, Synth. React. Inorg. Met.-Org. Chem., 32 (2002) 219-229.

[65] V.V. Pavlishchuk, A.W. Addison, Inorg. Chim. Acta, 298 (2000) 97-102. 